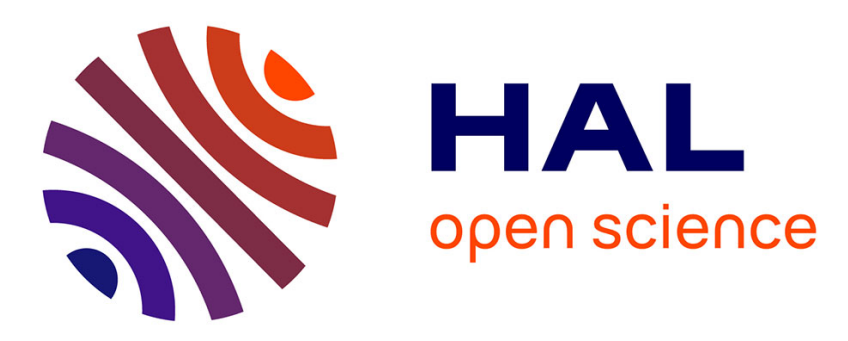

\title{
A natural coagulant protein from copra (Cocos nucifera): Isolation, characterization, and potential for water purification
}

\author{
J.K. Fatombi, B. Lartiges, T. Aminou, Odile Barres, C. Caillet
}

\section{To cite this version:}

J.K. Fatombi, B. Lartiges, T. Aminou, Odile Barres, C. Caillet. A natural coagulant protein from copra (Cocos nucifera): Isolation, characterization, and potential for water purification. Separation and Purification Technology, 2013, 116, pp.35-40. 10.1016/j.seppur.2013.05.015 . hal-02151878

\section{HAL Id: hal-02151878 \\ https://hal.science/hal-02151878}

Submitted on 10 Jun 2019

HAL is a multi-disciplinary open access archive for the deposit and dissemination of scientific research documents, whether they are published or not. The documents may come from teaching and research institutions in France or abroad, or from public or private research centers.
L'archive ouverte pluridisciplinaire HAL, est destinée au dépôt et à la diffusion de documents scientifiques de niveau recherche, publiés ou non, émanant des établissements d'enseignement et de recherche français ou étrangers, des laboratoires publics ou privés. 
1 A NATURAL COAGULANT PROTEIN FROM COPRA (COCOS NUCIFERA):

2 ISOLATION, CHARACTERIZATION, AND POTENTIAL FOR WATER

3 PURIFICATION

4 J. K. FATOMBI ${ }^{1,3 *}$, B. LARTIGES ${ }^{2,3}$, T. AMINOU ${ }^{1}$, O. BARRES ${ }^{3}$, C. CAILLET ${ }^{3}$.

5 1- Laboratoire d'Expertise et de Recherche en Chimie de l'Environnement et de l'Eau

6 (LERCEE) Faculté des Sciences et Techniques/Département de Chimie/Université d'Abomey-

7 Calavi, 01 BP 526, COTONOU (Bénin)

8 2- University of Toulouse - Geosciences Environment Toulouse - UMR CNRS-UPS-IRD

9 5563/234-14 Av. Edouard Belin-31400 Toulouse, France

10

3- Université de Lorraine - Laboratoire Environnement et Minéralurgie (LEM) UMR 7569

CNRS-INPL (ENSG) 15 Avenue du Charmois 54501 Vandouvre-lès Nancy (France)

Corresponding author: E-mail: jacquesfatombi@yahoo.fr

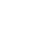

\footnotetext{
* Corresponding author : FATOMBI K. Jacques ; E-mail: jacquesfatombi@yahoo.fr
} 


\section{Abstract:}

A natural coagulant protein was extracted from the endosperm of Cocos nucifera, and characterized by Fourier Transform Infrared Spectroscopy, Size Exclusion Chromatography, potentiometric titration, electrophoretic mobility, and then tested for its coagulant properties using silica nanocolloids. The infrared spectra revealed predominant absorption bands at 1649 $\mathrm{cm}^{-1}$ and $1536 \mathrm{~cm}^{-1}$ characteristics of $-\mathrm{C}=\mathrm{O}$ in primary and secondary amides of proteins arranged into an alpha-helical secondary structure, and the presence of triolein when fat was not removed from the extract. The molecular weight determined by size exclusion chromatography was about $5.6 \mathrm{kDa}$, the charge density of the fat extracted protein being $1.05 \mathrm{meq} \cdot \mathrm{g}^{-1}$, and the isoelectric point 7.5 . The proteinous extracts behaved as effective coagulants of silica particles, the destabilisation mechanism being consistent with an heteroaggregation of oppositely charged colloids. Overall, the characteristics of that natural protein were closely similar to those of Moringa oleifera seed extract, thus suggesting that copra can be considered as a potential source of an efficient and sustainable coagulant for water treatment in emerging countries.

Keywords: Cocos nucifera - natural coagulant - water treatment .

Highlights: -A protein coagulant similar to Moringa Oleifera seed extract, was isolated from copra.
nanocolloids.

-Its potential for water purification was sucessfully tested with silica 


\section{1- Introduction}

In his book "The quest for pure water", Baker (1949) [1] relating the history of water purification, reveals that some nuts such as almonds in Egypt, Strychnos potatorum in India, or beans in Soudan, have been used in the ancient times to promote the coagulation of turbid waters. Although alum and other hydrolyzable metal salts have long supplanted those natural clarification aids, other nut-derived substances and plant extracts have recently been considered as potential coagulants and water softeners in emerging countries, where the access to classical inorganic coagulants is sometimes difficult [2-3]. Thus, Opuntia cactaceae [3-5], leaves of Cassia alata [6] and of Calotropis procera [7], and the now classical Moringa oleifera seeds [8-13], have been reported to yield macromolecules of promising coagulating properties that may reconcile a cost-effective water treatment with sustainable development [3, 14]. Until now, only the nature of active agent in Moringa oleifera seeds, i.e. a dimeric cationic polypeptide of 6-17 $\mathrm{kDa}$ molecular weight with a 10-11 isoelectric point, and the corresponding aggregation mechanism, have been investigated into details [8-11, 15-17].

Just like Moringa oleifera sometimes referred to as "the miracle tree", Coconut palm (Cocos nucifera) is a multipurpose tree which is a source of food, beverage, oilseed, fibre, charcoal, and health products, and is revered by people as "the tree of life". It widely grows across the world, (Asia, Africa, Caribbean, Latin America), and the overall coconut production has been estimated to be at least 61.7 million ton/year according to current FAO statistics. In a preliminary study, Fatombi et al. [18] showed that the casein cream extracted from the coconut endosperm possesses a coagulant activity similar to that of M. oleifera seeds, the two natural coagulants being tested on Okpara river water and synthetic suspensions prepared with kaolin particles. To better understand the origin of such coagulant activity, an improved characterization of coconut casein cream is needed. In the present paper, Fourier Transform Infrared Spectroscopy, potentiometric titration, electrophoretic mobility, 
and size exclusion chromatography, are used to characterize the properties of two caseins, i.e. with or without fat, extracted from the cream of Cocos nucifera. In addition, the aggregation mechanisms associated with those two natural coagulants are explored using silica nanocolloids, a typical component of surface waters which is frequently used to assess the efficiency of metal hydrolysable coagulants [20, 33]. Jar-tests, electrophoretic mobility measurements, and Transmission Electron Microscopy on ultrathin sections cut from resinembedded aggregates, were then used to describe the interaction between the silica particles and the two coconut caseins.

\section{2- Experimental section}

\section{1- Extraction of casein from coconut cream}

The coconuts were purchased from the local markets of Cotonou (Benin Republic). Mature coconuts were first dehusked and cracked to remove coconut water. About a hundred grams of finely grated coconut endosperm obtained with a vegetable grater, were then added to $500 \mathrm{~mL}$ of distilled water. After shaking for $10 \mathrm{~min}$, the mixture thus obtained was filtered through a $80 \mu \mathrm{m}$-mesh sieve, and the liquid collected was separated between an aqueous phase (coconut milk) and an organic phase (coconut cream). Hydrochloric acid 1M solution was then added to $100 \mathrm{~mL}$ of coconut cream until the precipitation of casein occurred. The casein precipitate was separated from oil and hydrochloric acid residues by centrifugation at 3500 rpm for $20 \mathrm{~min}$. The pellet of raw casein was oven-dried at $40^{\circ} \mathrm{C}$ during 24 hours and is further referred to as CaMG (casein with fat). In addition, a fat-free casein named CaSMG hereafter, was also obtained by extraction with hexane in a soxlhet extractor. The coagulant solution was prepared by adding two grams of either CaMG or CaSMG to $100 \mathrm{~mL}$ of distilled water, and the mixture was then agitated at room temperature for two hours.

\section{2- Characterization of caseins}


The infrared spectra of CaSMG and CaMG caseins were recorded with a Fouriertransform infrared spectrometer (Bruker IFS55) equipped with a DTGS detector in the transmission mode. $1 \mathrm{mg}$ of casein was mixed with about $150 \mathrm{mg} \mathrm{KBr}$ (FTIR grade), and a pellet was prepared using a $10 \mathrm{~T}$ press. The spectra were recorded in the $4000-400 \mathrm{~cm}^{-1}$ range with 64 scans collected at $2 \mathrm{~cm}^{-1}$ resolution.

The electrophoretic mobility of CaSMG and CaMG suspensions (40mg/L of each casein in $\mathrm{NaCl} 0.1 \mathrm{M}$ ) was determined with a zetaphoremeter IV (CAD Instrumentation, France) equipped with a CCD camera. The electrophoretic mobility was obtained by measuring the direction and velocity of particles in the applied electric field $(800 \mathrm{~V} / \mathrm{m})$.

The charge density of coconut caseins was determined by potentiometric titration (Titrando $809 \mathrm{Metrohm})$ at $25^{\circ} \mathrm{C}$ under an inert nitrogen atmosphere. The titration was carried out with $100 \mathrm{mg}$ of a given casein suspended into $50 \mathrm{~mL} \mathrm{NaNO}_{3} 0.1 \mathrm{M}$ solution as a function of titrant volume $\left(\mathrm{HNO}_{3} \quad 0.1 \mathrm{M}\right.$ or $\left.\mathrm{NaOH} 0.1 \mathrm{M}\right)$. Before analysis, the suspension was allowed to stabilize for $1 \mathrm{~h}$ under magnetic stirring and nitrogen stream. A quick step titration in acid-tobasis direction from natural $\mathrm{pH}$ to $\mathrm{pH} 10$ was first recorded in order to reach the $\mathrm{pH}$ considered as the $\mathrm{pH}$ origin of the following titration curve used for the charge density determination. The second titration was then performed in the basic-to-acid direction from $\mathrm{pH}$ 10 to $\mathrm{pH}$ 3. The reference curve was recorded by titration of the pure electrolyte solution $\mathrm{NaNO}_{3} 0.1 \mathrm{M}$ under the same conditions. In the case of a solid/electrolyte interface, protons or hydroxyls can be used to probe the surface charge density. Hence, the proton consumption (PC in $\mu \mathrm{mol} / \mathrm{g}$ ) was calculated according to the method reported by Prelot et al. [19], i.e. PC $=$ $\Delta \mathrm{V} \mathrm{Clm}$, where $\Delta \mathrm{V}$ is the difference between the volume of titrant added to the suspension $\left(\mathrm{V}_{\mathrm{s}}\right)$ and that added to the reference electrolyte $\left(\mathrm{V}_{\mathrm{r}}\right)\left(\Delta \mathrm{V}=\mathrm{V}_{\mathrm{s}}-\mathrm{V}_{\mathrm{r}}\right), C$ being the titrant concentration and $m$ the mass of solid (g). 

inferred using size exclusion chromatography equipped with a GF-250 9.4x250mm column that can separate soluble macromolecules in water in the $4 \mathrm{kDa}-400 \mathrm{kDa}$ molecular weight range. The column was calibrated with standard proteins: thyroglobulin $670 \mathrm{kDa}, \operatorname{IgG} 160$ $\mathrm{kDa}$, apo-transferrin $78 \mathrm{kDa}$, bovine albumin $66 \mathrm{kDa}$, chicken albumin $44.3 \mathrm{kDa}$, myoglobulin $17.6 \mathrm{kDa}$, ribonuclease A $13.7 \mathrm{kDa}$, and insulin $5.73 \mathrm{kDa}$. A few micrograms of each standard protein were dissolved in $\mathrm{NaCl} 0.2 \mathrm{M}$ solution, and the calibration curve was obtained from a plot of the logarithm of the molecular weight versus elution time. CaSMG and CaMG samples were prepared by dissolving $50 \mathrm{mg}$ of each casein in $2.5 \mathrm{~mL} \mathrm{NaCl} 0.2 \mathrm{M}$ solution. After shaking for two hours, the suspension was filtered on a membrane $(0.45 \mu \mathrm{m}$ pore size). About $100 \mu \mathrm{L}$ of filtrate were injected in the column, the elution being performed with $\mathrm{NaCl} 0.2 \mathrm{M}$ solution at a $1 \mathrm{~mL} \cdot \mathrm{min}^{-1}$ rate. The proteins were detected by UV spectrophotometry with the detection wavelength set at a $215.8 \mathrm{~nm}$.

\section{3- Preparation of colloidal suspensions and aggregation procedure}

The silica suspensions were prepared by diluting Ludox HS 40 (Aldrich) at 100, 250, 500 and 750mg/L with deionised water (Millipore, MilliQ). $336 \mathrm{mg} / \mathrm{L}$ of $\mathrm{NaHCO}_{3}$ were added to give a buffer capacity similar to that of a surface water [20]. The $\mathrm{pH}$ of silica suspensions was adjusted at 6 with dropwise addition of $\mathrm{HCl} 0.1 \mathrm{~N}$ solution. The Ludox silica used in this study is an alkaline aqueous dispersion of non porous spherical particles $14 \mathrm{~nm}$ in diameter. Unlike kaolin particles used in our previous study [18] that present a shape factor and two types of surfaces (edge and basal), the spherical precipitated Ludox silica with an energetically homogeneous surface [35] makes a better model for investigating the aggregation mechanisms with the coconut caseins. In addition, it was previously used to 
assess the coagulating properties of WAC HB (Water Aluminum Chloride High Basicity) $[20]$.

Mixing of the silica suspensions with the natural coagulant was carried out in a $150 \mathrm{~mL}$ glass beaker reactor equipped with four Plexiglas baffles to avoid the formation of a vortex at high mixing speed. The reactor is fitted with a rectangular paddle located at $1 / 3$ of the beaker height from the bottom. The synthetic suspension was agitated at $250 \mathrm{rpm}$ for $2 \mathrm{~min}$; the selected volume of CaMG or CaSMG coagulant solution was then added with an Eppendorf micropipette $(100-1000 \mu \mathrm{L})$. The stirring rate was maintained at $250 \mathrm{rpm}$ for $3 \mathrm{~min}$, and then was decreased at $60 \mathrm{rpm}$ for $20 \mathrm{~min}$. At the end of stirring, the aggregated suspension was allowed to settle for $30 \mathrm{~min}$ in a graduated Imhoff cone.

$50 \mathrm{~mL}$ of supernatant were siphoned out from $25 \mathrm{~mm}$ under the free water surface. The supernatant was analysed for $\mathrm{pH}$ (WTW LF 340), residual turbidity (HACH 2100P), and electrophoretic mobility (CAD Instrumentation Zetaphoremeter). The sludge volume was measured by reading the graduation marks on the side of the Imhoff cone.

Transmission electron Microscopy observation of aggregates was performed with a Philips CM 20 operating at $200 \mathrm{kV}$, on ultrathin slices obtained from resin-embedded samples. The sludge was first fixed with $2 \%$ osmium tetroxide. After one hour of reaction, excess of treated water was removed and replaced with solutions of acetone in water $(10 \%$, $20 \%, 40 \%, 60 \%, 80 \%, 90 \%$ and then $100 \%)$. The samples were then impregnated in an epoxy resin (Epon 812, Euromedex). Impregnated samples were placed in molds and polymerized in an oven at $60^{\circ} \mathrm{C}$ for 24 hours. The blocks obtained were cut using a Reichert OM U2 ultramicrotome. The sections were mounted on a carbon-coated copper grid and stained with lead citrate and uranyl acetate.

\section{3- Results and discussion}


Both caseins were analysed by FTIR to assess the nature of active functional groups in

CaSMG and CaMG coagulants. As illustrated in figure 1, similar absorption bands at 1649 $\mathrm{cm}^{-1}, 1536 \mathrm{~cm}^{-1}$, and $1237 \mathrm{~cm}^{-1}$, can be recognized in both CaSMG and CaMG spectra. These peaks are characteristic of carbonyl $\mathrm{C}=\mathrm{O}$ stretching vibrations in primary, secondary, and tertiary amides, respectively [21], the positions of those infrared bands being consistent with the presence of $\alpha$-helices in the secondary structure of proteins $[17,22]$. The rather broad peaks around $3411 \mathrm{~cm}^{-1}$ and $3290 \mathrm{~cm}^{-1}$ can be assigned to the stretching vibrations of $\mathrm{O}-\mathrm{H}$ and $\mathrm{N}-\mathrm{H}$ and to intermolecular hydrogen bonds within the caseins macromolecules, respectively [23].

\section{Figure 1: FTIR spectra of CaMG and CaSMG}

The CaMG spectrum also reveals intense infrared bands at 1746, 2924, 2854, and $2956 \mathrm{~cm}^{-1}$. The strong peak at $1746 \mathrm{~cm}^{-1}$, attributed to the $\mathrm{C}=\mathrm{O}$ stretching vibration of the carbonyl groups in methyl esters and triglycerides, has been identified in the infrared spectrum of cashew nut kernel [24]. The classical bands at 2924, 2854, and $2956 \mathrm{~cm}^{-1}$ are assigned to $\mathrm{C}-\mathrm{H}$ asymmetric and symmetric stretching in $\mathrm{CH}_{2}$ and $\mathrm{C}-\mathrm{H}$ asymmetric stretching in $\mathrm{CH}_{3}$, respectively. Those infrared signals are typical of compounds containing long alkyl chains, and their absence in the CaSMG spectrum validates the fat extraction from the casein. The remaining bands at $1467 \mathrm{~cm}^{-1}$ and $1162 \mathrm{~cm}^{-1}$ likely identify the $\mathrm{CH}_{2}$ scissors deformation vibration and the $\mathrm{C}=\mathrm{O}$ bending vibration, respectively. Interestingly, the infrared bands typical of the fats contained in CaMG and removed during the hexane treatment, are comparable with those of triolein, a triglyceride of oleic acid found in a number of oily nuts [24-25]. On the other hand, the abundant presence of amide functional groups in the caseins is consistent with a proteinous nature of those compounds. Moreover, the infrared spectrum of 
CaSMG is similar to that of purified active protein in Moringa oleifera seeds used for aggregation of colloidal particles [17].

\section{Figure 2: Size exclusion chromatograms of CaMG and CaSMG}

The size exclusion chromatograms of CaMG and CaSMG are shown in figure 2. CaMG is eluted as two main peaks detected at retention times of 14.15 and 16.8 min, whereas CaSMG appears as a single peak at about 14 min with a minor shoulder around 16.2 min.

Obviously, the purified compound in CaSMG chromatogram corresponds to the proteinous matter identified by FTIR. From the calibration curve relating the molecular weight of standard proteins to elution time, a molecular weight of about $5.6 \mathrm{kDa}$ can be calculated. Interestingly, the flocculating activity of $M$. oleifera seeds has been attributed to proteins of molecular weight ranging from 6 to $17 \mathrm{kDa}[8,9,11,13,16,26,27]$. The second peak at 16.8 min retention time on CaMG chromatogram is tentatively attributed to the triolein-like fat.

Figure $3 \mathrm{a}$ shows the proton binding isotherms inferred from the potentiometric titration curves of CaMG and CaSMG. Curves with similar shape are obtained for the two caseins. The negative values obtained above $\mathrm{pH} 3$ for $\mathrm{CaMG}$ and $\mathrm{pH} 3.4$ for CaSMG, indicate a release of protons from caseins, whereas the positive values correspond to an adsorption of protons. At first approximation, it can be considered that the fat associated with CaMG casein do not present any major titratable functional groups, and hence, that the difference between the two curves correspond to the weight of fat in casein. Therefore, CaMG should contain almost equivalent amounts of protein and fat. The net charge densities obtained from the titration curves of CaMG and CaSMG, are 0.47 and $1.09 \mathrm{meq} / \mathrm{g}$, respectively. Such values are lower than that of chitosan $(4.5 \mathrm{meq} / \mathrm{g})$ [32], but remain close to the $1.2-7.3 \mathrm{meq} / \mathrm{g}$ charge density range of usual commercial cationic polyelectrolytes [28]. 

Evolution of electrophoretic mobility as a function of pH for CaMG and CaSMG caseins.

The electrophoretic mobility of both CaMG and CaSMG caseins as a function of $\mathrm{pH}$ is shown in figure 3b. An identical Point of Zero Mobility (PZM) of 7.5 is found for both coagulants, which, in accordance with the potentiometric titration results presented above, indicates that the fat in CaMG does not significantly contribute to the charge of that extract. The difference between the $\mathrm{pH}$ at no proton release $(\sim 3.5)$ and the point of zero mobility $(7.5)$ likely originates from the organization of the protein coagulant as a soft particle permeable towards ions and hydric fluxes [35]. The PZM of active protein in coconut casein is lower than the value $\sim 10$ reported in the literature for the purified protein contained in Moringa oleifera seeds $[8,13,29]$, thus suggesting a higher content in carboxylic groups in coconut caseins.

\section{2- Jar-test results}

Figure 4a compares the performance of CaSMG and CaMG in terms of turbidity removal and sludge volume in the case of $250 \mathrm{mg} / \mathrm{L}$ silica nanocolloids suspensions aggregated at $\mathrm{pH}$ 6. Similar patterns are obtained for both coagulants: the residual turbidities increase steadily at low casein concentration as small non-settleable aggregates are formed, and after reaching a maximum, decrease steeply with further addition of coagulants as settling aggregates are then produced. At higher casein concentrations, the supernatant turbidities remain low and practically constant in the range of dosages investigated. In parallel, the sludge volumes rapidly increase after the respective maxima in residual turbidity, to reach an identical and steady plateau value. In other words, the amount of sludge obtained during the jar-test does not depend on the type of casein used. This implies that the quantity of silica 
particles is a main determining parameter for sludge volume, as confirmed by the proportional relationship between these two variables established for a series of jar-tests performed with varying concentrations in silica colloids (figure $4 \mathrm{~b}$ ). The supernatant $\mathrm{pH}$ of the treated water remained essentially constant with only a small decrease of $0.3 \mathrm{pH}$ units at high coagulant concentration.

Figure 4: a) Variation of residual turbidity (solid curves) and sludge volume (hyphenated curves) as a function of casein concentration for both CaMG and CaSMG ; OCC indicates the Optimum Coagulant Concentration. b) Variation of maximum sludge as a function of silica concentration for casein CaSMG.

The optimum coagulant concentration (OCCs) is defined as the minimum dosage needed to attain the low residual turbidity value. It may seem paradoxical to obtain a residual turbidity at OCC higher than that of the untreated suspension. However, the light scattered by a few non-settleable fractal aggregates in the micron size range is certainly much higher than that of all dispersed elementary nanoparticles. According to figure 4a, CaSMG is more effective than CaMG, especially that a slightly lower residual turbidity and a smaller sludge volume are obtained at the OCC. However, the difference between the two OCCs, $80 \mathrm{mg} / \mathrm{L}$ and $100 \mathrm{mg} / \mathrm{L}$ for CaSMG and CaMG respectively, is much less than expected if charge neutralization was the direct aggregation mechanism. Indeed, as the charge density of CaMG is about half that of CaSMG, the corresponding OCC should be double of that associated with CaSMG. In comparison, the OCC recorded with WAC HB - a commercial aluminum chlorosulfate coagulant - to treat a $250 \mathrm{mg}$ silica suspension at $\mathrm{pH} 6$ was about $3 \mathrm{mg} / \mathrm{L}$ of $\mathrm{Al}$.

TEM examination of silica nanocolloids aggregated with CaSMG casein at the OCC (figure 5) reveals relatively compact clusters of particles and small organic fibrils originating from the unfiltered coagulant solution before addition. The cationic protein, which according 
to its $5.6 \mathrm{kDa}$ molecular weight should be in the nanometer size range [30], likely corresponds to the dark heavy metal-stained grains present at the surface of some silica nanocolloids. It should be noted that the silica particles embedded in the bulk of the resin ultrathin section can be visualized because of mass contrast, but that the coagulant organic matter associated with them can not be stained with heavy metal salts.

Figure 5: TEM micrograph of resin-embedded sludge (CaSMG + silica suspension at 120mg/L) pH=6 (a: compact clusters of silica colloids; b: small organic fibrils; c: coagulant protein)

Figure 6a shows the variation of electrophoretic mobility of particles remaining in the supernatant after settling, as a function of casein concentration. For both CaSMG and CaMG, the electrophoretic mobility of residual aggregates increases with coagulant concentration first rapidly up to the OCC, and then more slowly at higher dosages. However, even above OCCs, the complete neutralization of silica colloids can not be achieved. Actually, the mobility curves do not provide any precise indication regarding the optimal coagulation range. Similar electrokinetic behaviors were reported by Jerri et al. [31] for Moringa oleifera cationic protein adsorbed on sand granules, and for Opuntia spp. coagulant with kaolin particles [3].

Figure 6: a) Variation of electrophoretic mobility of treated water at $\mathbf{p H = 6}$; b) Evolution of OCC as a function of silica nanocolloid concentration at $\mathbf{p H}=6$.

Nevertheless, as illustrated in figure $6 b$, the optimum coagulant concentration is proportional to the amount of silica particles in suspension, such stoichiometric relation being usually interpreted as resulting from a charge neutralization mechanism [28]. Moreover, the ratio of slopes of OCC-silica amount curves for CaSMG and CaMG is about 2, i.e. approximately the ratio of charge densities measured for the two caseins. The aggregation mechanism of silica particles by caseins is therefore related to charge neutralization, even 
though the charge of colloids can not be reversed at high dosages. A key observation made by Kwaambwa et al. [10] is that the coagulant protein from Moringa oleifera seeds has been shown by neutron reflectivity to adsorb cooperatively at the surface of silicon oxide. Therefore, silica nanocolloids could be aggregated by clusters of coconut protein of increasing size with coagulant concentration, the aggregation phenomenon being equivalent to an heteroaggregation of oppositely charged colloids. It should be noted that the residual fat associated with the protein coagulant could play a significant role in such cluster formation.

\section{4- Conclusion}

This study demonstrates that an effective coagulant protein can be extracted from the coconut endosperm. This water soluble protein has a $5.6 \mathrm{kDa}$ molecular weight and a 7.5 isoelectric point. The destabilisation mechanism of silica particles seems to be related to an heteroaggregation between oppositely charged colloids, the protein component likely forming clusters of increasing size with coagulant concentration. Preliminary jar-tests conducted at $\mathrm{pH}$ 8 with the fat free casein (CaSMG) showed only a $25 \%$ increase of the Optimum Coagulant Concentration for a $250 \mathrm{mg} / \mathrm{L}$ silica suspension. This suggests that the natural coagulant protein extracted from copra can certainly be effective over the range of natural water $\mathrm{pH}$.

Further work is obviously needed to check whether the coconut protein also possesses efficient antimicrobial and water softening properties, just like the protein extracted from Moringa oleifera seeds. Interestingly, Cocos nucifera is essentially grown in the intertropical zone where precipitations exceed $2000 \mathrm{~mm}$, whereas Moringa oleifera is also present in semiarid areas. This suggests that both trees can be considered as a potential source of natural coagulant in complementary geographical areas. 


\section{Acknowledgements}

The authors would like to thank the "Agence Universitaire de la Francophonie", (AUF) for granting a post doctoral research fellowship to Jacques K. FATOMBI during its stay at the University of Lorraine (Laboratoire Environnement et Minéralurgie (LEM)).

\section{References}

[1] M.N. Baker, The quest for pure water : the history of water purification from the earliest records to the twentieth century, American Water Works Association, New York (1949).

[2] J.P. Sutherland, G.K. Folkard, W.D Grant, Natural coagulants for appropriate water treatment: a novel approach, Waterlines 8(4) (1990) 30-32.

[3] S.M. Miller, F. Ezekiel, C. Vinkaoyanedel, S. James, Z. Andjulieb, Toward Understanding the Efficacy and Mechanism of Opuntia spp. As a Natural Coagulant for Potential Application in Water Treatment, Environ. Sci. Technol. 42 (2008) 4274-4279.

[4] A. Abid, A. Zouhri, A. Ider, Utilisation d'un nouveau bio-floculant extrait de cactus marocain dans le traitement des rejets chargés de chrome (VI) par le procédé de coagulation floculation, Afr. Sci. 5(3) (2009) 25-35.

[5] J. Zhang, F. Zhang, Y. Luo, H. Yang, A preliminary study on cactus as coagulant in water treatment, Process Biochem. 41 (2006) 730-733.

[6] E.R. Aweng, I. Anwar, M.I. Siti Rafiqah, O. Suhaimi, Cassia alata as a potential coagulant in water treatment, Res. J. Recent Sci. 1(2) (2012) 28-33.

[7] B.O. Shittu, T.O.S. Popoola, O. Taiwo, Potentials of Calotropis procera leaves for wastewate treatment, Proceedings of the International Conference on Science \& National Development, (2004) 97-101.

[8] M. Broin, C. Santaella, S. Cuine, K. Kokou, G. Peltier, T. Joe, Flocculent activity of a 
recombinant protein from Moringa oleifera Lam. seeds, Appl. Microbiol. Biotechnol. 60(1-2) (2002) 114-119.

[9] G. Kebreab, K.R. Gunaratna, H. Hongbin, B. Harry, D. Gunnel, A simple purification and activity assay of the coagulant protein from Moringa oleifera seed, Water Research. 39 (2005) $2338-2344$.

[10] H.M. Kwaambwa, H. Maja, R. Adrian, Adsorption of a Water Treatment Protein from Moringa oleifera Seeds to a Silicon Oxide Surface Studied by Neutron Reflection, Langmuir 26(6) (2010) 3902-3910.

[11] M. Suarez, J.M. Entenza, C. Doerries, E. Meyer, L. Bourquin, J. Sutherland, I. Marison, P. Moreillon, N. Mermod, Expression of a plant-derived peptide harboring water-cleaning and antimicrobial activities, Biotechnol Bioeng. 81(1) (2003) 13-20.

[12] S.A.A. Jahn, Drinking water from Chinese rivers: Challenges of clarification, J. Wat. SRT, 50(1) (2001) 15-27.

[13] T. Okuda, A.U. Baes, W. Nishijima, M. Okada, Isolation and characterization of coagulant extracted from Moringa oleifera seed by salt solution, Water Res. 35 (2) (2001) $405-410$.

[14] S. Kawamura, Effectiveness of natural polyelectrolyte in water treatment, J. Am. Water Works Assoc. 83 (1991) 88-91.

[15] R.S. Ferreira, T.H. Napoleão, A.F. Santos, R.A. Sa, M.G. Carneiro-da-Cunha, M.M. Morais, R.A. Silva-Lucca, M.L. Oliva, L.C. Coelho, P.M. Paiva, Coagulant and antibacterial activities of the water-soluble seed lectin from Moringa oleifera. Lett. Appl. Microbiol., 53 (2011) 186-192.

[16] A. Ndabigengesere, K. Narasiah, B.G. Talbot, Active agents and mechanisms of coagulation of turbid water using Moringa oleifera, Wat. Res. 29(2) (1995) 703-710. 
[17] H.M. Kwaambwa, R. Maikokera, Infrared and circular dichroism spectroscopic characterisation of secondary structure components of a water treatment coagulant protein extracted from Moringa oleifera seeds, Colloids Surf. B: Biointerface, 64 (2008) 118-125.

[18] K.J. Fatombi, R.G. Jossè, D. Mama, T. Aminou, Etude de l'activité floculante de la caséine acide de la crème de Cocos nucifera sur la clarification des eaux de surface, Rev. Sci. Eau, 22(1) (2009) 93-101.

[19] B. Prelot, W. Janusz, F. Thomas, F. Villiéras, R. Charmas, W. Piasecki, W. Rudzinski, Adsorption of cadmium ions at the electrolyte/silica interface 1. Experimental study of surface properties. Appl. Surf. Sci., 196, (2002) 322-330.

[20] B.S. Lartiges, J.Y. Bottero, L.S. Derrendinger, B. Humbert, P. Tekely, H. Suty, Flocculation of Colloidal Silica with Hydrolyzed Aluminum: An ${ }^{27}$ Al Solid State NMR Investigation, Langmuir, 13 (1997) 147-152.

[21] A. Dong, J. Matsuura, S.D. Allison, E. Chrisman, M.C. Manning, J.F. Carpenter, Infrared and circular dichroism spectroscopic characterization of structural differences betweenlactoglobulin A and B, Biochem. 35 (1996) 1450-1457.

[22] K. Griebenow, A. Klibanov, Lyophilization-induced reversible changes in the secondary structure of proteins. Biochem. 92 (1995) 10969-10976.

[23] W. Jian-Ping, C. Yong-Zhen, Y. Shi-Jie, S. Guo-Ping, Y. Han-Qing, Synthesis and characterization of a novel cationic chitosan-based flocculant with a high water-solubility for pulp mill wastewater treatment, Wat. Res. 43 (2009) 5267-5275.

[24] A.G. Barua, S. Hazarika, M. Hussain, A.K. Misra, Spectroscopic investigation of the Cashew Nut Kernel (Anacardium Occidentale), The Open Food Sci. J., 2, (2008) 85-88. 
[25] M.L.S. Albuquerque, I. Guedes, Jr. P. Alcantara, S.G.C. Moreira, Infrared absorption spectra of Buriti (Mauritia flexuosa L.) oil, Vib. Spectrosc., 33 (2003) 127-131.

[26] E. Ali, S. Muyibi, H. Salleh, M. Alam, M.Salley, Production of Natural Coagulant from Moringa oleifera Seed for Application in Treatment of Low Turbidity Water, J. Wat. Resource Protect., 2 (2010) 259-266.

[27] U. Gassenschmidt, J. Klaus, T. Bernhard, N. Heinz, Isolation and characterization of a flocculating protein from Moringa oleifera Lam, Biochim. Biophys. Acta 1243, (1995) 477481.

[28] B. Bolto, Gregory J., Organic polyelectrolytes in water treatment, Wat. Res. 41 (2007) 2301-2324.

[29] G. Folkard, J. Sutherland, R.S. Al-Khalili, La clarification de l'eau par coagulation en utilisant les graines du Moringa oleifera. In : L. Fuglie (2002) L'arbre de la vie, les multiples usages du Moringa. CWS/CTA, Dakar, Sénégal. pp 79-82.

[30] H.P. Eriksson, Size and shape of protein molecules at the nanometer level determined by sedimentation, gel filtration, and electron microscopy, Biological Procedures Online, 11(1) (2009) 32-51.

[31] H.A. Jerri, K.J. Adolfsen, L.R. McCullough, D. Velegol, S.B. Velegol, Antimicrobial Sand via Adsorption of Cationic Moringa oleifera Protein, Langmuir, 28 (4) (2012) 22622268.

[32] R. Rojas-Reyna, S. Schwarz, G. Heinrich, G. Petzold, S. Schütze, J. Bohrisch, Flocculation efficiency of modified water soluble chitosan versus commonly used commercial polyélectrolytes, Carbohydrate Polymers 81, (2010) 317-322. 
398 [33] J. Duan, J. Gregory, Influence of soluble silica on coagulation by aluminium sulphate., 399 Colloids Surfaces A, 107, (1996), 309-319.

400 [34] J.F.L. Duval, F. Gaboriaud, Progress in electrohydrodynamics of soft microbial particle 401 interphases, Curr. Opin. Colloid Interface Sci., 15(3), (2010) 184-195.

402 [35] M.A.V. Axelos, D. Tchoubar, J.Y. Bottero, Small-angle X-ray scattering investigation of 403 the silica/water interface: evolution of the structure with pH, Langmuir, 5, (1989) 1186-1190. 